Article

\title{
Osmanicin, a Polyketide Alkaloid Isolated from Streptomyces osmaniensis CA-244599 Inhibits Elastase in Human Fibroblasts
}

\author{
Mamdouh N. Samy ${ }^{1}{ }^{1}$, Géraldine Le Goff ${ }^{1}$, Philippe Lopes ${ }^{1}$, Katerina Georgousaki ${ }^{2}$, \\ Sentiljana Gumeni ${ }^{3}$, Celso Almeida ${ }^{4}$, Ignacio González ${ }^{4}{ }^{\circledR}$, Olga Genilloud ${ }^{4}{ }^{\circledR}$, \\ Ioannis Trougakos ${ }^{3}\left(\right.$, Nikolas Fokialakis ${ }^{2}$ (D) and Jamal Ouazzani ${ }^{1, *(1)}$ \\ 1 Institut de Chimie des Substances Naturelles ICSN, Centre National de la Recherche Scientifique, \\ Avenue de la Terrasse, 91198 Gif-sur-Yvette, France; mamdouhnabil.2006@yahoo.com (M.N.S.); \\ Geraldine.LEGOFF@cnrs.fr (G.L.G.); Philippe.LOPES@cnrs.fr (P.L.) \\ 2 Department of Pharmacognosy \& Natural Products Chemistry, Faculty of Pharmacy, National and \\ Kapodistrian University of Athens, 15771 Athens, Greece; kat_georgousaki@hotmail.com (K.G.); \\ fokialakis@pharm.uoa.gr (N.F.) \\ 3 Department of Cell Biology and Biophysics, Faculty of Biology, National and Kapodistrian University of \\ Athens, 15784 Athens, Greece; sgumeni@biol.uoa.gr (S.G.); itrougakos@biol.uoa.gr (I.T.) \\ 4 Fundación MEDINA, Parque Tecnológico de Ciencias de la Salud, 18016 Granada, Spain; \\ celsoguerreiro@gmail.com (C.A.); ignacio.gonzalez@medinaandalucia.es (I.G.); \\ olga.genilloud@medinaandalucia.es (O.G.) \\ * Correspondence: jamal.ouazzani@cnrs.fr; Tel.: +33-682816590
}

Received: 24 May 2019; Accepted: 12 June 2019; Published: 15 June 2019

\begin{abstract}
The strain Streptomyces osmaniensis CA-244599 isolated from the Comoros islands was submitted to liquid-state fermentation coupled to in situ solid-phase extraction with amberlite XAD-16 resin. Elution of the trapped compounds on the resin beads by ethyl acetate afforded seven metabolites, osmanicin (1), streptazolin (2), streptazone C (3), streptazone $B_{1}(4)$, streptenol C (5), nocardamine (6) and desmethylenylnocardamine (7). Osmanicin (1) is a newly reported unusual scaffold combining streptazolin (2) and streptazone C (3) through a Diels-Alder type reaction. Experimental evidence excluded the spontaneous formation of $\mathbf{1}$ from $\mathbf{2}$ and $\mathbf{3}$. The isolated compounds were evaluated for their ability to inhibit elastase using normal human diploid fibroblasts. Compound $\mathbf{1}$ exhibited the most potent activity with an $\mathrm{IC}_{50}$ of $3.7 \mu \mathrm{M}$.
\end{abstract}

Keywords: Streptomyces osmaniensis; in situ solid-phase extraction; osmanicin; alkaloids; elastase inhibition

\section{Introduction}

The Streptomyces genus belongs to the gram-positive actinobacteria phylum and is among the most prolific producers of diverse and bioactive secondary metabolites. These metabolites belong to different structural classes, including polyketides, peptides, terpenoids, alkaloids and hydrazides [1], which exhibit a wide range of biological activities such as antibiotic (vancomycin, erythromycin and tetracycline), antifungal (amphotericin B), anticancer (mitomycin C), antiparasitic (ivermectin) and immunosuppressive (rapamycin) activities [2].

Although Streptomyces species from terrestrial and marine ecosystems have been intensively investigated in recent decades, there still remains a pool of unexplored diversity of secondary metabolites. This discovery pipeline is continuously fed through innovative experimental strategies [3] and genome-based approaches [4]. 
The present study was conducted in the frame of our screening program to discover bioactive metabolites from microorganisms of global biodiversity with skin related anti-wrinkle properties [5]. Among our targets, elastase, that is a matrix metalloproteinase (MMP), constitutes a key enzyme involved in the degradation of proteins contained in skin connective tissue. Elastases are serine proteases that break elastin fibers and regulates, together with collagenases, the mechanical properties of the skin including elasticity, strength, tissue remodeling, and wound healing capacity [6]. Under normal physiological conditions, the activity of elastase is precisely regulated to ensure skin tissue homeostasis. Following oxidative stress or UV light exposure, elastase is overexpressed, resulting in skin disorders such as premature skin aging, inflammation, or more seriously, degenerative diseases [7]. Moreover, the age-related upregulation of fibroblast elastase was correlated to an increase of advanced glycation end products [8]. The search for natural substances able to inhibit elastase is thus of great interest for the cosmetic and/or pharmaceutical industries.

During our screening program a collection of 100 selected microbial strains, covering worldwide diversity, were grown in ten different nutritional conditions and their extracts were screened as potential elastase inhibitors. Among them, an extract from the Streptomyces strain CA-244599 exhibited a significant inhibitory effect against elastase in cell free assays and then in a human skin fibroblast cell line (CCD25SK) while had no cytotoxicity in cancer cell lines (A2058, HepG2). Phylogenetic analysis based on $16 \mathrm{~S}$ rRNA gene sequences has confirmed that the isolated strain belongs to the genus Streptomyces and is closely related to the species Streptomyces osmaniensis OU-63 ${ }^{\mathrm{T}}$. To the best of our knowledge the type species $S$. osmaniensis has never been investigated for its bioactive metabolites.

In the frame of the current work, we describe herein the scale-up isolation and characterization of a new elastase inhibitor together with six previously described metabolites that have potential applications in the cosmetic industry.

\section{Results and Discussion}

The Streptomyces strain CA-244599 was isolated from a soil sample collected from a savannah environment at Bangouamafsakoa, in the Comoros Islands. The strain was confirmed as Streptomyces by molecular analysis according to its $16 \mathrm{~S}$ rRNA and tentatively assigned to the species S. osmaniensis by following phylogenetic analysis (Figure 1).

The strain was cultivated in Potatoes Dextrose Broth (PDB) medium in a $20 \mathrm{~L}$ fermenter (12 L working volume) coupling liquid-state fermentation with in situ solid-phase extraction using Amberlite XAD-16 neutral resin $[9,10]$. After five days of cultivation, the resin was recovered by filtration and washed extensively with water. The compounds were eluted from the resin by ethyl acetate followed by methanol, and analyzed by HPLC coupled with PDA, LSD, MS detectors and were evaluated for their activity in cell-based (BJ cells) assays at the concentration of 1 and $10 \mu \mathrm{g} / \mathrm{mL}$ (Figure 2).

All analyzed extracts displayed a statistically significant inhibition of elastase activity in a dose dependent way. Specifically, the ethyl acetate extract showed the highest inhibition by $66.2 \%$ at $1 \mu \mathrm{g} / \mathrm{mL}$ and $82.4 \%$ at $10 \mu \mathrm{g} / \mathrm{mL}$. The analytical HPLC chromatogram of this extract indicated the presence of 7 peaks, which were purified by Flash chromatography followed by semi-preparative HPLC. Among them, the structure of a previously undescribed compound osmanicin (1) was elucidated using 1D- and 2D-NMR spectroscopic analyses and high-resolution mass spectrometry. Besides the new compound, the previously described streptazolin (2) [11], streptazone C (3) and B (4) [12], streptenol C (5) [13], nocardamine (6) [14] and desmethylenylnocardamine (7) [15] were also isolated (Figure 3). 


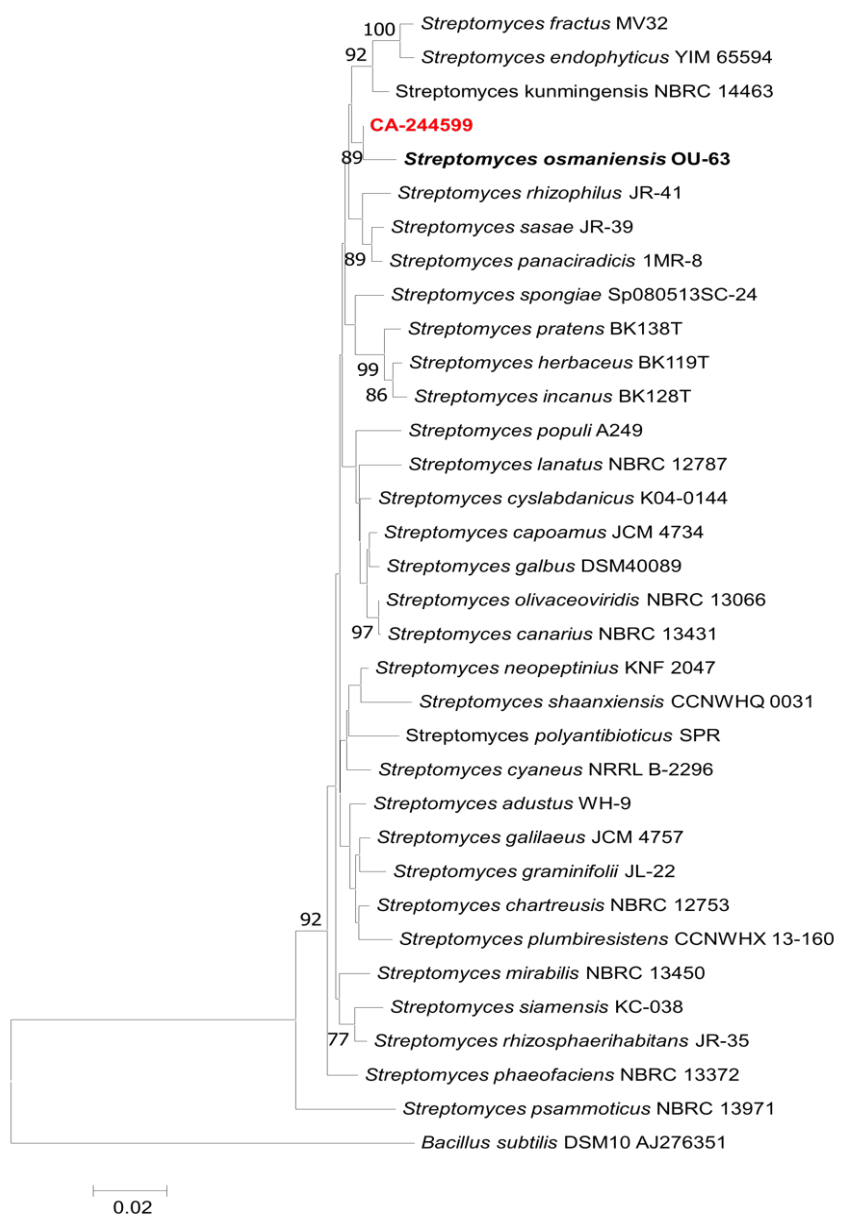

Figure 1. Phylogenetic analysis of Actinomycete isolate CA-244599.

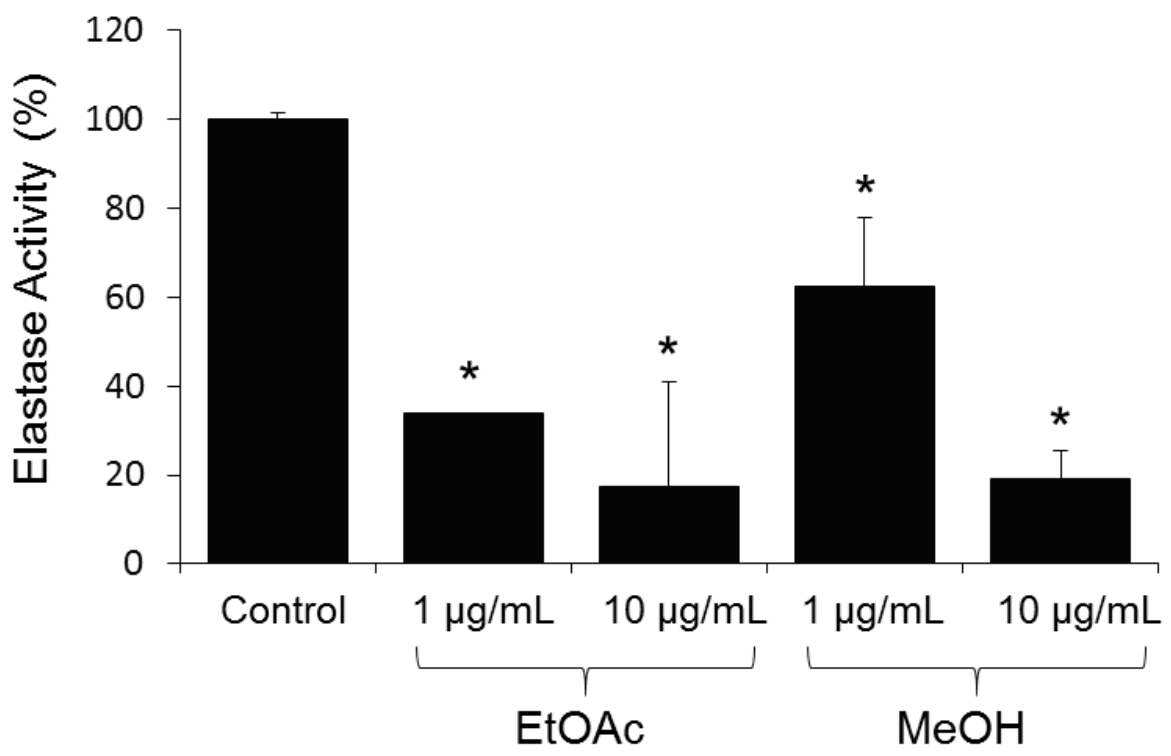

Figure 2. Relative (\%) elastase inhibitory activity in normal human BJ fibroblasts after $24 \mathrm{~h}$ of treatment with shown extracts at the concentration of 1 and $10 \mu \mathrm{g} / \mathrm{mL}$. Values from controls (cells treated without the extract) were set to $100 \%$. Data are presented as mean \pm SD $(n \geq 3)$. The statistical differences observed in the graphic are significant when compared to control samples, ${ }^{*} p<0.05$. 


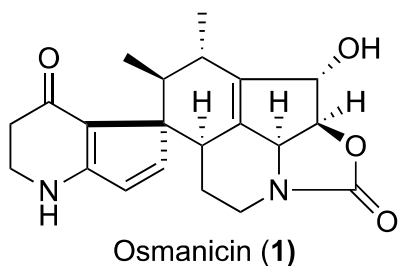

Osmanicin (1)

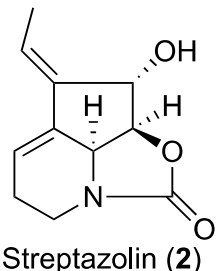

Streptazolin (2)<smiles>C/C=C1/C=CC2=C1C(=O)CCN2</smiles><smiles>C/C=C1/C(=O)C=C2NCCC=C21</smiles><smiles>CC=CC=CC(=O)C[C@@H](O)CCO</smiles>

Streptazone C (3) Streptazone B (4)

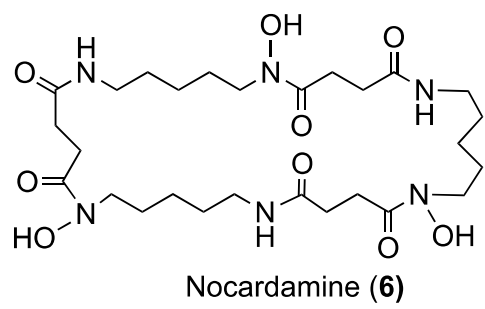

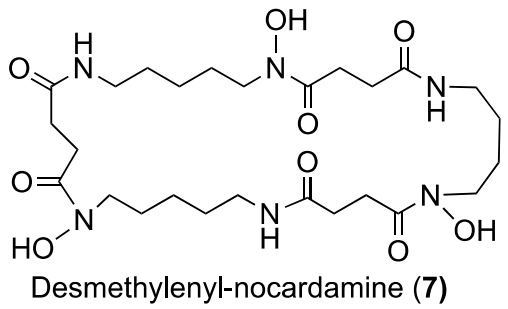

Figure 3. Compounds isolated from Streptomyces osmaniensis CA-244599.

The molecular formula of 1 was deduced as $\mathrm{C}_{21} \mathrm{H}_{24} \mathrm{~N}_{2} \mathrm{O}_{4}$ on the basis of HRESIMS with $\mathrm{m} / \mathrm{z}$ $369.1826[\mathrm{M}+\mathrm{H}]^{+}$. The IR spectrum showed absorptions indicating the presence of hydroxyl groups $\left(3279 \mathrm{~cm}^{-1}\right)$ and a carbonyl group $\left(1737 \mathrm{~cm}^{-1}\right)$. The ${ }^{1} \mathrm{H}-\mathrm{NMR}$ spectrum of $\mathbf{1}$ (Table 1 ) displayed signals corresponding to two doublet olefinic protons at $\delta_{\mathrm{H}} 6.33(\mathrm{~d}, J=5.8 \mathrm{~Hz})$ and $6.78(\mathrm{~d}, J=5.8 \mathrm{~Hz})$, two doublet methyls at $\delta_{\mathrm{H}} 0.62(\mathrm{~d}, J=7.1 \mathrm{~Hz})$ and $1.05(\mathrm{~d}, J=7.4 \mathrm{~Hz})$, three oxymethine protons at $\delta_{\mathrm{H}} 4.53(\mathrm{br} \mathrm{s}), 4.68(\mathrm{~m})$ and $4.69(\mathrm{~m})$, as well as three methine and four methylene protons (refer to Supplementary Information).

The ${ }^{13} \mathrm{C}$-NMR spectrum of $\mathbf{1}$ (Table 1 ) revealed the presence of 21 carbon signals, including two carbonyls at $\delta_{C} 185.7$ and 160.0 , two methyls at $\delta_{C} 12.8$ and 13.4 , in addition to two olefinic carbons, three oxymethines, three methines, four methylenes and four quaternary carbon signals. Comparing spectroscopic data with those from literature, we found that compound 1 consisted of the attachment of streptazolin (2) and streptazone C (3). The attachment of the two compounds was confirmed by ${ }^{1} \mathrm{H}-{ }^{1} \mathrm{H}$ COSY and HMBC correlations (Figure 4). The ${ }^{1} \mathrm{H}-{ }^{1} \mathrm{H}$ COSY correlations confirmed the linkage of $\mathrm{H}_{3}-22 / \mathrm{H}-7 / \mathrm{H}-8 / \mathrm{H}_{3}-23$. The methyl protons $\mathrm{H}_{3}-22\left(\delta_{\mathrm{H}} 1.05\right)$ showed significant HMBC correlations with C-6 $\left(\delta_{C} 61.0\right), C-7\left(\delta_{C} 38.9\right)$ and C-8 $\left(\delta_{C} 33.2\right)$, confirming its attachment to C-6, whereas the other methyl group $\mathrm{H}_{3}-23\left(\delta_{\mathrm{H}} 0.62\right)$ was correlated with $\mathrm{C}-7\left(\delta_{\mathrm{C}} 38.9\right), \mathrm{C}-8\left(\delta_{\mathrm{C}} 33.2\right)$ and $\mathrm{C}-9\left(\delta_{\mathrm{C}} 141.3\right)$, indicating its attachment to $\mathrm{C}-9$. This was also supported by key HMBC correlations between the methine proton H-7 $\left(\delta_{\mathrm{H}} 2.81\right)$ and C-6 $\left(\delta_{\mathrm{C}} 61.0\right), \mathrm{C}-21\left(\delta_{\mathrm{C}} 154.6\right)$ and C-22 $\left(\delta_{\mathrm{C}} 12.8\right)$ and between the methine proton H-8 $\left(\delta_{C} 2.60\right)$ and $C-6\left(\delta_{C} 61.0\right)$ and $C-23\left(\delta_{C} 13.4\right)$. These findings were strongly indicative to the cyclization between the two exocyclic ethylidene side chains. 
Table 1. NMR spectroscopic data $\left(\mathrm{CD}_{3} \mathrm{OD}\right)$ for osmanicin (1).

\begin{tabular}{|c|c|c|c|}
\hline \multicolumn{4}{|c|}{ Osmanicin (1) ${ }^{a}$} \\
\hline No. & $\delta_{C}$, type & $\delta_{\mathrm{H}}$, mult. $(J$ in $\mathrm{Hz})$ & НМBC \\
\hline 2 & $43.4, \mathrm{CH}_{2}$ & 3.62, bt $(7.4)$ & $C-3,4,19$ \\
\hline 3 & $36.2, \mathrm{CH}_{2}$ & $2.39,(\mathrm{dt}(8.4,3.9)$ & $C-2,4,5$ \\
\hline 4 & $185.7, \mathrm{C}$ & & \\
\hline 5 & $112.4, \mathrm{C}$ & & \\
\hline 6 & $61.0, \mathrm{C}$ & & \\
\hline 7 & $38.9, \mathrm{CH}$ & $2.81, \mathrm{~b}$ quint $(7.6)$ & $C-6,21,22$ \\
\hline 8 & $33.2, \mathrm{CH}$ & $2.60, \mathrm{~m}$ & C-6, 23 \\
\hline 9 & $141.3, \mathrm{C}$ & & \\
\hline 10 & $80.0, \mathrm{CH}$ & $4.68, \mathrm{~m}$ & C-9, 11 \\
\hline 11 & $83.5, \mathrm{CH}$ & $4.69, \mathrm{~m}$ & $C-10,12,13,18$ \\
\hline 12 & $64.5, \mathrm{CH}$ & $4.53, \mathrm{~b} \mathrm{~d}(1.4)$ & C-18 \\
\hline 13 & $138.7, \mathrm{C}$ & & \\
\hline 14 & $38.8, \mathrm{CH}$ & $3.36, \mathrm{~m}$ & $C-13,16$ \\
\hline 15 & 28.6, $\mathrm{CH}_{2}$ & $\begin{array}{c}1.02, \mathrm{~m} \\
1.41, \mathrm{~d} \text { quint }(13.3,2.9)\end{array}$ & \\
\hline 16 & 43.6, $\mathrm{CH}_{2}$ & $\begin{array}{l}3.11, \mathrm{td}(13.3,3.2) \\
3.58, \mathrm{dd}(5.1,2.3)\end{array}$ & C-18 \\
\hline 18 & $160.0, C$ & & \\
\hline 19 & $169.2, \mathrm{C}$ & & \\
\hline 20 & 127.4, $\mathrm{CH}$ & $6.33, \mathrm{~d}(5.8)$ & $C-5,6,19,21$ \\
\hline 21 & 154.6, $\mathrm{CH}$ & $6.78, \mathrm{~d}(5.8)$ & $C-5,6,20$ \\
\hline 22 & $12.8, \mathrm{CH}_{3}$ & $1.05, \mathrm{~d}(7.4)$ & $C-6,7,8$ \\
\hline 23 & $13.4, \mathrm{CH}_{3}$ & $0.62, \mathrm{~d}(7.1)$ & $C-7,8,9$ \\
\hline
\end{tabular}

${ }^{\mathrm{a}}{ }^{1} \mathrm{H}$ and ${ }^{13} \mathrm{C}$ chemical shifts were recorded at 300 and $75 \mathrm{MHz}$ respectively.

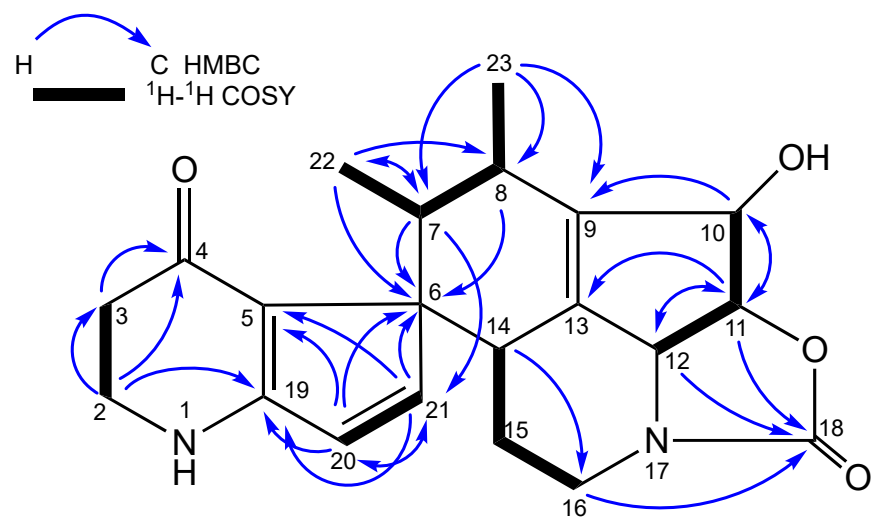

Figure 4. Key COSY and HMBC correlations for compound 1.

The spectroscopic data of the isolated streptazolin are identical to previous publications reporting the absolute stereochemistry of $2[16,17]$. We thus attributed the configuration of C-10, C-11 and C-12 in 1.

ROE correlations between $\mathrm{H}-11$ and $\mathrm{H}-12$ and the absence of correlation between $\mathrm{H}-10, \mathrm{H}-12$, and $\mathrm{H}-11, \mathrm{H}-12$ confirmed the stereochemistry of the streptazolin moiety.

In Figure 5, ROE correlations between H-11, H-12 and H-14, between $\mathrm{H}-14$ and $\mathrm{H}-7$ and between $\mathrm{H} 10$ and $\mathrm{H} 8$, allow the assignment of the stereochemistry at the newly generated asymmetric centers C-14, C-7 and C-8. The configuration of the quaternary carbon 6 was deduced from ROE correlations between $\mathrm{H}-21$ and $\mathrm{H}-14, \mathrm{H}-22, \mathrm{H}-23$ and confirmed according to the 3D structure obtained by Chem3D (ChemBio3D, Perkin Elmer) (Figure 5) (ROE, Rotating-frame Overhauser Enhancement). 

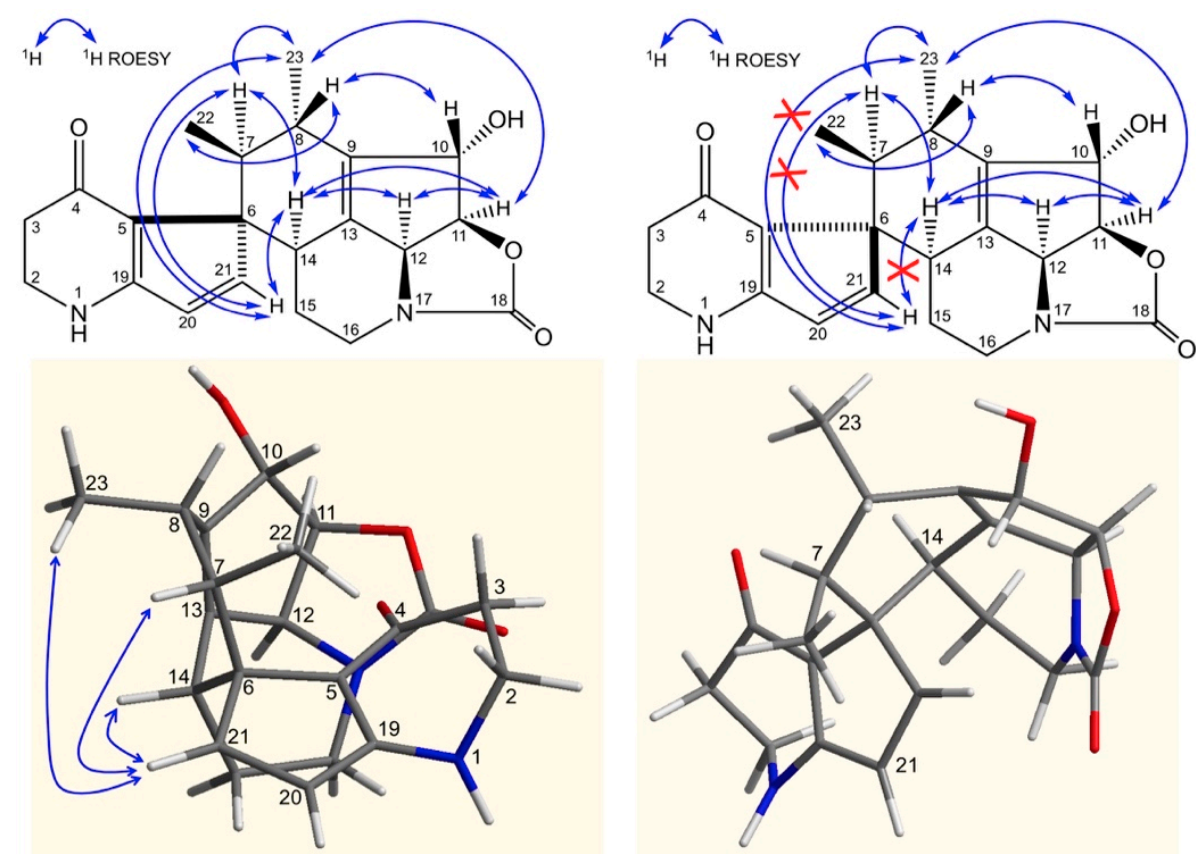

Figure 5. Confirmation of the stereochemistry at C-6.

Therefore, compound 1 exhibits a $6 S, 7 S, 8 S, 10 S, 11 S, 14 S$ configuration and was named osmanicin.

The complete biosynthesis of polyketide alkaloids in Streptomyces is not yet elucidated. However, some common features were recently published involving a type I polyketide synthase (PKS) associated with a $\omega$-transaminase located genetically close to the PKS cluster [18]. This pathway is considered common to all the polyketide alkaloids especially streptazones and streplazolin. Based on these considerations, compound $\mathbf{1}$ may derives from a combination between streptazone $\mathrm{C}$ and streplazolin through a Diels-Alder type reaction (Figure 6) $[19,20]$. Although Diels-Alder cycloaddition is a key reaction in organic chemistry, its enzymatic counterpart has been highlighted in different biosynthesis of natural products [20]. Even if most of the reactions are intramolecular, few intermolecular cases were reported, even if they have been the subject of particular controversy [21,22]. Recently, many groups have engaged the optimization of specific Diels-Alder biocatalysts by combining targeted mutagenesis, computational refinement and directed evolution [23,24]. We recently reported the case of sporochartine involving a tentative Diels-Alderase intermolecular cycloaddition [25]. Sporochartine and osmanicin represents the targets of our future investigations in the field.

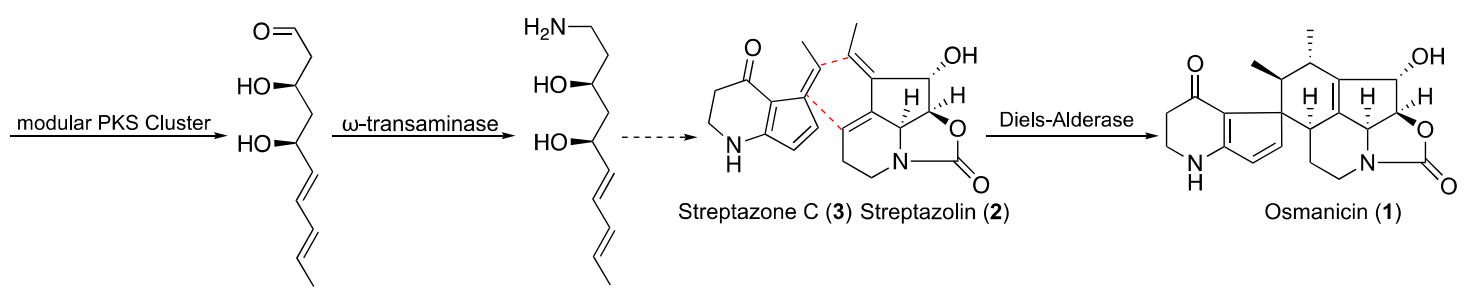

Figure 6. The proposed biosynthetic pathway of osmanicin (1).

Streptazolin (2), streptazone C (3), streptazone B (4), nocardamine (6) and desmethylenyl-nocardamine (7) were previously reported from terrestrial Streptomyces spp as previously indicated.

The compounds were then screened on a cell-based bioassay for their effect on elastase activity. Normal human diploid fibroblasts (BJ cells) were incubated with $5 \mu \mathrm{M}$ of concentration for each compound, and after $24 \mathrm{~h}$ of incubation elastase activity was measured. Compounds 1, 2, 3, 6 and 7 exhibit a statistically significant inhibition ranging from 48.8 to $77.7 \%$ compared to the non-treated 
cells, with the highest inhibition being observed for osmanicin (1) (Figure 7). Compounds 4 and $\mathbf{5}$ did not exhibit any significant activity (not shown).

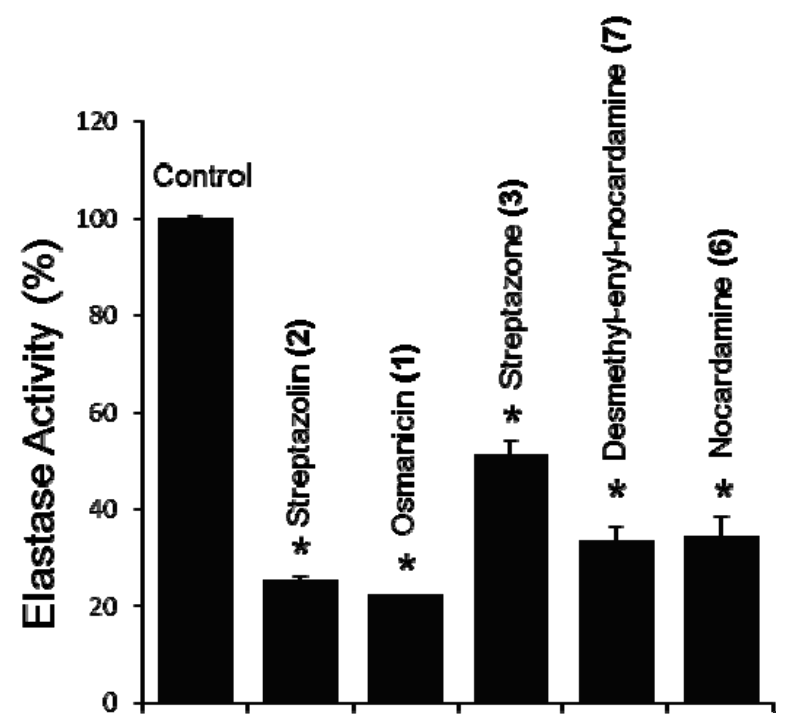

Figure 7. Relative (\%) elastase inhibitory activity in human fibroblasts after $24 \mathrm{~h}$ of treatment with pure compounds at the concentration $5 \mu \mathrm{M}$. Values from controls (cells treated without the extract) were set to $100 \%$. Data are presented as mean $\pm \operatorname{SD}(n=3)$. Shown differences are significant vs. control samples, ${ }^{*} p<0.05$.

Normal fibroblasts were then incubated for $24 \mathrm{~h}$ at different concentrations to obtain the $\mathrm{IC}_{50}$ inhibitory values of osmanicin against elastase. The $\mathrm{IC}_{50}$ value of elastase inhibition was found to be $3.7 \mu \mathrm{M}$ (Figure 8A). Furthermore, BJ normal human fibroblasts were treated for $24 \mathrm{~h}$ with increasing concentrations of osmanicin $(1 \mu \mathrm{M}$ to $5 \mu \mathrm{M})$ in order to evaluate the toxicity of the compound. Under these experimental conditions, osmanicin showed some minor toxicity $(p=0.0425)$ only at the concentration of $5 \mu \mathrm{M}$ (Figure 8B).
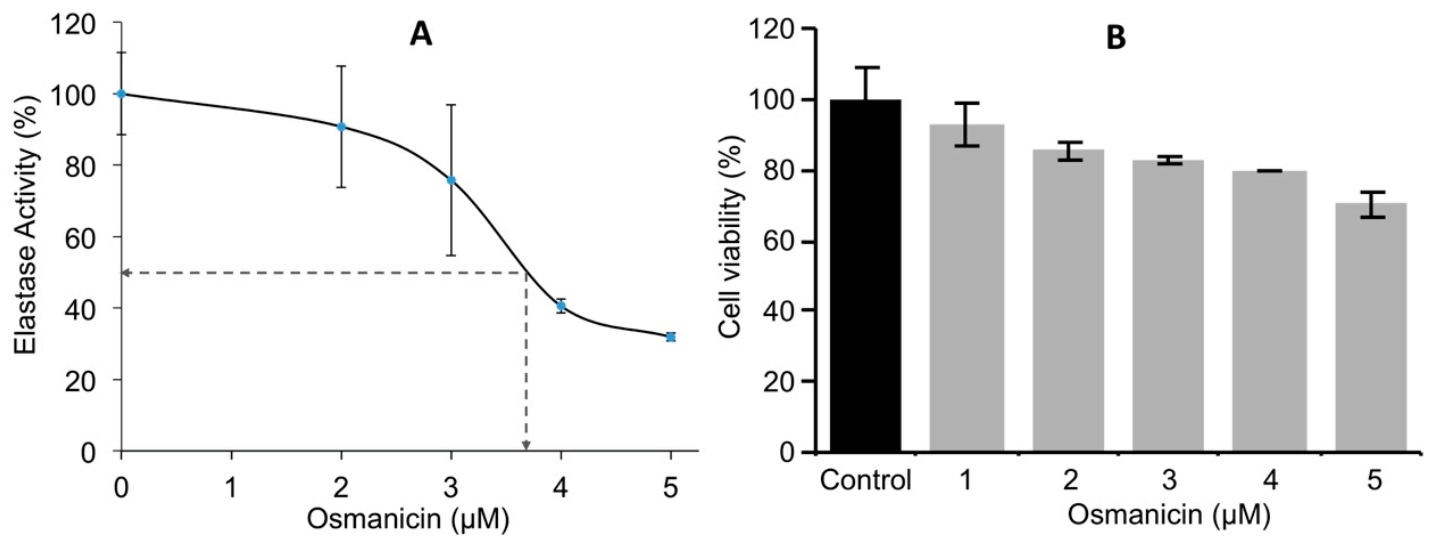

Figure 8. Determination of the $\mathrm{IC}_{50}$ inhibitory concentration of osmanicin against elastase (A) and cell survival after osmanicin treatment (B). (A) The half maximal inhibitory concentration ( $\mathrm{IC}_{50}$ ) of osmanicin against elastase was calculated by plotting the graph between the different concentrations used $(1 \mu \mathrm{M}$ to $5 \mu \mathrm{M})$ and the $\%$ inhibition of elastase activity. Data are presented as mean $\pm \operatorname{SD}(n \geq 3)$. (B) Relative (\%) survival (MTT assay) of BJ fibroblasts exposed to the indicated concentrations of osmanicin for $24 \mathrm{~h}$. Data are presented as mean $\pm \operatorname{SD}(n \geq 3)$.

Given the overall lifespan increase in the western world, there is a growing interest in skin health and in products that likely delay skin aging processes. The main symptoms of skin aging are 
the wrinkling and sagging due to the loss of flexibility and elasticity. These processes are (among others) driven by the enzymatic activity of elastases. Reportedly, aging leads to the upregulation of elastase activity and therefore to tissue destruction and loss of elasticity [26]. We show herein that the ethyl acetate extract of the strain Streptomyces osmaniens is CA-244599 exerts an inhibitory activity against elastase in normal human fibroblasts. Our assays were performed in human fibroblasts elastase, in order to examine the proprieties of the isolated extracts/pure compounds in preventing the proteolytic degradation of dermal elastic fibers. Our data showed a significant decrease of elastase activity in a dose-dependent manner. Therefore, the herein described extracts/pure compounds from Streptomyces osmaniensis can be likely considered as anti-wrinkling agents in the industry of cosmetics. Furthermore, we fully characterized the extract of Streptomyces osmaniensis, and our data revealed that all the isolated compounds inhibited the activity of skin fibroblasts elastase. In addition, we identified osmanicin a new, non-previously described metabolite, which showed the greatest inhibitory $(77 \%)$ effect on elastase activity. Overall, our data suggest that extracts of Streptomyces osmaniensis, along with osmanicin may be used as an effective biomaterial in skin anti-aging treatments as it can likely reduce the degradation of the dermal fibers by inhibiting elastase activity.

\section{Materials and Methods}

\subsection{General Experimental Procedures}

Optical rotations $[\alpha]_{D}$ were measured using an Anton Paar MCP-300 polarimeter at $589 \mathrm{~nm}$. The IR spectra were obtained using a Perkin-Elmer Spectrum 100 model instrument. NMR experiments were performed using a Bruker Avance $500 \mathrm{MHz}$ spectrometer (Bruker Biospin, Wissembourg, France). All the spectra were acquired in $\mathrm{CD}_{3} \mathrm{OD}\left(\delta_{\mathrm{H}} 3.31 \mathrm{ppm}\right.$ and $\left.\delta_{\mathrm{C}} 49.15 \mathrm{ppm}\right)$ at room temperature. High-resolution mass spectra were obtained on a Waters LCT Premier XE spectrometer equipped with an ESI-TOF (electrospray-time of flight) by direct infusion of the purified compounds. Pre-packed silica gel Redisep columns were used for flash chromatography using a Combiflash-Companion chromatogram (Serlabo, Entraigues sur La Sorgue, France). All other chemicals and solvents were purchased from SDS (eypin, France).

Analytical HPLC system consisted of an Alliance Waters 2695 controller coupled with a PhotoDiode Array Waters 2996, an evaporative light-scattering detector ELSD Waters 2424 detector and a mass detector Waters QDa. Sunfire $\mathrm{C}_{18}$ column $(4.6 \times 150 \mathrm{~mm}, 3.5 \mu \mathrm{m})$ was used with a flow rate of $0.7 \mathrm{~mL} / \mathrm{min}$. The elution gradient consisted of a linear gradient from $100 \%$ solvent A to $100 \%$ solvent $\mathrm{B}$ in $40 \mathrm{~min}$, then $10 \mathrm{~min}$ at $100 \% \mathrm{~B}$ (Solvent $\mathrm{A}: \mathrm{H}_{2} \mathrm{O}+0.1 \mathrm{HCOOH}$, Solvent $\mathrm{B}: \mathrm{ACN}+0.1 \% \mathrm{HCOOH}$ ). Preparative HPLC was performed on a semi-preparative Sunfire $C_{18}$ column $(10 \times 250 \mathrm{~mm}, 5 \mu \mathrm{m})$ using a Waters autosampler 717, a pump 600, a photodiode array detector 2996 and an ELSD detector 2420 (Waters, Guyancourt, France).

\subsection{Bacterial Strain}

The Streptomyces strain CA-244599 was isolated from a dry soil sample collected in the savannah of Bangouamafsakoa in the Comoros Islands. This soil was air dried and suspended in sterile water. The soil suspension was serially diluted, plated on selective isolation media and incubated at $28^{\circ} \mathrm{C}$ for at least six weeks. The strain was isolated from an NZ-amine-based agar medium containing nalidixic acid $(20 \mu \mathrm{g} / \mathrm{mL})$. The colony was purified on yeast-malt extract glucose medium (ISP2) and preserved as frozen agar plugs in $10 \%$ glycerol.

\subsection{S rDNA Sequence and Phylogenetic Analysis}

Total genomic DNA was recovered and purified as previously described [27] from the strain grown in ATCC-2 liquid medium (0.5\% yeast extract (Difco, Franklin Lakes, NJ, USA), 0.3\% beef extract (Difco), $0.5 \%$ peptone (Difco), $0.1 \%$ dextrose (Difco), $0.2 \%$ starch from potato (Panreac, Barcelona, Spain), $0.1 \%$ CaCO3 (E. Merck, Darmstadt, Germany) and 0.5\% NZ amine E (Sigma, St Louis, MO, USA). DNA 
preparations were used as template DNA for Taq Polymerase. PCR primers fD1 and rP2 were used for amplifying the $16 \mathrm{~S}$ ribosomal RNA gene of the strain [28,29]. Reactions were performed in a final volume of $50 \mu \mathrm{l}$ containing $0.4 \mu \mathrm{M}$ of each primer, $0.2 \mathrm{mM}$ of each of the four deoxyribonucleotide triphosphates (Roche, Indianapolis, IN, USA), $5 \mu$ l of extracted DNA, 1 U Taq polymerase (Appligene, Watford, UK) with its recommended reaction buffer. PCR amplifications were performed in a Peltier Thermal Cycler PTC-200, according to the following profile: $5 \mathrm{~min}$ at $95^{\circ} \mathrm{C}$ and 40 cycles of $30 \mathrm{~s}$ at $94{ }^{\circ} \mathrm{C}, 30 \mathrm{~s}$ at $52{ }^{\circ} \mathrm{C}$ for and $1 \mathrm{~min}$ at $72{ }^{\circ} \mathrm{C}$, followed by $10 \mathrm{~min}$ at $72{ }^{\circ} \mathrm{C}$. The amplification products were analyzed by electrophoresis in $2 \%(w / v)$ pre-cast agarose gels stained with ethidium bromide (E-gel 2\%, 48 wells, Invitrogen, Carlsbad, CA, USA). PCR products were sent to Secugen (Madrid, Spain) for sequencing and were purified and used as a template in sequencing reactions using the primers fD1 and rP2 $[23,24]$. Amplified DNA fragments were sequenced using the ABI PRISMDYE Terminator Cycle sequencing kit and fragments were resolved using the ABI3130 genetic analyzer (Applied Biosystems, Foster City, CA, USA). Partial sequences were assembled and edited using the Assembler contig editor component of Bionumerics (ver 6.6) analysis software (Applied Maths NV, Sint-Martens-Latem, Belgium).

The almost-complete 16S rRNA gene sequence (1,329 nucleotides Genbank access MH443355) of strain CA-244599 was compared to those deposited in public databases and the EzBiocloud server (https://www.ezbiocloud.net) [30]. The strain exhibited the highest similarity (99.10\%) with was Streptomyces osmaniensis OU-63 ${ }^{\mathrm{T}}$ (FJ613126), using EzBiocloud and GenBank sequence similarity searches and homology analysis. Phylogenetic and molecular evolutionary analyses were conducted using MEGA version 6 [31]. Multiple alignment was carried out using CLUSTALX [32], integrated in the software. The phylogenetic analysis, based on the Neighbor-Joining method [33] using matrix pairwise comparisons of sequences corrected with Jukes and Cantor algorithm [34], shows that the strain is closely related to the type strain Streptomyces osmaniensis OU-63 ${ }^{\mathrm{T}}$ and this relatedness is well supported in the analysis by the bootstrap value (97\%). The morphological, 16S rRNA gene sequence and phylogenetic data were indicative that strain CA-244599 is a member of the genus Streptomyces and the strain is tentatively referred as Streptomyces osmaniensis CA-244599.

\subsection{Fermentation, Isolation and Structure Elucidation of Compounds}

The original production was performed in $1 \mathrm{~L}$ volume of the liquid medium FRM. The first seed culture of the strain CA-244599 was prepared by inoculating $50 \mathrm{~mL}$ of seed medium (soluble starch (20 g/L), dextrose (10 g/L), NZ amine EKC (Sigma) (5 g/L), Difco beef extract (3 g/L), Bacto peptone $(5 \mathrm{~g} / \mathrm{L})$, yeast extract $(5 \mathrm{~g} / \mathrm{L})$, and $\mathrm{CaCO} 3(1 \mathrm{~g} / \mathrm{L})$, adjusted to $\mathrm{pH} 7.0$ with $\mathrm{NaOH}$ before addition of $\mathrm{CaCO}_{3}$ ), in $250 \mathrm{~mL}$ flasks with $2.5 \mathrm{~mL}$ of a frozen inoculum stock of the producing strain and incubating the tube at $28{ }^{\circ} \mathrm{C}$ and $220 \mathrm{rpm}$ agitation for $48 \mathrm{~h}$. A 5\% aliquot of the seed culture was transferred to eight $500 \mathrm{~mL}$ flasks containing $150 \mathrm{~mL}$ of the FRM production medium (glycerol (Panreac 141339) (20 g/L), Dextrin from corn Type I (SIGMA D2006) (20 g/L), Bacto Soytone (Difco 243620) (3 g/L), $\left(\mathrm{NH}_{4}\right)_{2} \mathrm{SO}_{4}$ (Panreac 141140) (2 g/L) and CaCO3 (Merck 8605747) (3 g/L), adjusted to pH 7.4 prior to the addition of $\mathrm{CaCO}_{3}$ ). The flasks were incubated at $28{ }^{\circ} \mathrm{C}$ for seven days in a rotary shaker at 220 r.p.m. and $70 \%$ humidity before been harvested.

Batch fermentation of Streptomyces osmaniensis CA-244599 was conducted in a 15 L fermentor (Chemap $20 \mathrm{~L}$ unit) in a PDB medium over five days at $28^{\circ} \mathrm{C}$ with an aeration rate of 0.5 volumes of air per volume per minute, $100 \mathrm{rpm}$ agitation and $\mathrm{pH}$ of 6.6. Amberlite XAD-16 $(30 \mathrm{~g} / \mathrm{L}) \mathrm{was}$ added prior to sterilization to allow the in situ trapping of the microbial metabolites.

The XAD-16 resin was separated from the broth culture via filtration and washed with water before being eluted successively with EtOAc and $\mathrm{MeOH}(3 \times 500 \mathrm{~mL}$, each). The eluate was concentrated to dryness in vacuo yielding $1.26 \mathrm{~g}$ of EtOAc and $8.59 \mathrm{~g}$ of $\mathrm{MeOH}$ extracts.

The EtOAc extract (1.26 g) was subjected to flash chromatography on a Combiflash Companion using a Redisep $40 \mathrm{~g}$ silica column, with a heptane-ethyl acetate mixture serving as the eluent giving 10 fractions. The fourth fraction $\left(132.5 \mathrm{mg}\right.$ ) was purified by $\mathrm{HPLC}\left(30 \% \mathrm{CH}_{3} \mathrm{CN}\right.$ with $0.1 \%$ formic acid) 
to afford compound $3(67.4 \mathrm{mg})$. The sixth fraction $(50.6 \mathrm{mg})$ was purified by HPLC $\left(30 \% \mathrm{CH}_{3} \mathrm{CN}\right.$ with $0.1 \%$ formic acid) to furnish compound $4(11.0 \mathrm{mg})$. The seventh fraction $(62.3 \mathrm{mg})$ was purified by $\mathrm{HPLC}\left(\mathrm{H}_{2} \mathrm{O}-\mathrm{CH}_{3} \mathrm{CN}\right.$ gradient supplemented with $0.1 \%$ formic acid (100-0 to $\left.0-100\right)$ to produce compound 5 ( $4.2 \mathrm{mg})$. The tenth fraction $(190.4 \mathrm{mg})$ was purified by $\mathrm{HPLC}\left(\mathrm{H}_{2} \mathrm{O}-\mathrm{CH}_{3} \mathrm{CN}\right.$ gradient supplemented with $0.1 \%$ formic acid (100-0 to $0-100)$ to give compounds $1(8.9 \mathrm{mg})$ and 2 (2.4 mg).

The $\mathrm{MeOH}$ extract $(4.25 \mathrm{~g}$ ) was subjected to flash chromatography on a Combiflash Companion using a Redisep $80 \mathrm{~g}$ silica column, with a $\mathrm{CH}_{2} \mathrm{Cl}_{2}-\mathrm{MeOH}$ mixture serving as the eluent giving 9 fractions. The seventh fraction $(315.4 \mathrm{mg})$ was purified by $\mathrm{HPLC}\left(\mathrm{H}_{2} \mathrm{O}-\mathrm{CH}_{3} \mathrm{CN}\right.$ gradient supplemented with $0.1 \%$ formic acid (100-0 to 0-100)) to give compounds $6(2.3 \mathrm{mg})$ and $7(1.7 \mathrm{mg})$.

Osmanicin (1): Yellowish residue; $[\alpha]^{25} \mathrm{D}-92$ (c 0.10, MeOH); UV (MeOH) $\lambda \max (\log \varepsilon) 243$ (5.79), 345 (5.44) nm; IR (film) $v_{\max } 3279,2965,1737,1616,1571,1544,1519,1451,1412,1329,1218,1098,1032$, $767 \mathrm{~cm}^{-1}$; ${ }^{1} \mathrm{H}-\mathrm{NMR}\left(300 \mathrm{MHz}, \mathrm{CD}_{3} \mathrm{OD}\right)$ and ${ }^{13} \mathrm{C}-\mathrm{NMR}\left(75 \mathrm{MHz}, \mathrm{CD}_{3} \mathrm{OD}\right)$ see Table 1 ; HRESIMS $\mathrm{m} / \mathrm{z}$ $[\mathrm{M}+\mathrm{H}]^{+} 369.1826$ (Calcd for $\mathrm{C}_{21} \mathrm{H}_{25} \mathrm{~N}_{2} \mathrm{O}_{4}, 369.1814$ ).

\subsection{Cell Based Elastase Bioassay}

Proliferating normal human diploid fibroblasts (BJ cells) were cultured as described before [35]. In order to evaluate elastase activity, the amount of released $p$-nitroaniline, which was hydrolyzed from the substrate ( $N$-succinyl-Ala-Ala-Ala- $p$-nitroanilide) by elastase, was determined by measuring the absorbance at $405 \mathrm{~nm}$. Thus, BJ fibroblasts were seeded into 96-well microplates and the next day they were treated with compounds 1 to 7 at a final concentration of $5 \mu \mathrm{M}$ for each compound and of $1 \mu \mathrm{g} / \mathrm{mL}$ or $10 \mu \mathrm{g} / \mathrm{mL}$ of concentration for each extract, for $24 \mathrm{~h}$. Afterwards, cells were lysed in $100 \mathrm{mM}$ Tris-HCl (pH 7.6) with $0.1 \%$ Triton X-100 buffer and subsequently, $2 \mathrm{mM} \mathrm{N}$-succinyl-Ala-Ala-Ala-p-nitroanilide (Sigma-Aldrich) was added to each well followed by incubation at $37^{\circ} \mathrm{C}$ for $1 \mathrm{~h}$. The absorbance at $405 \mathrm{~nm}$ was measured using a microplate reader Infinite 200 PRO series (Tecan Trading AG, Switzerland).

\subsection{Determination of Osmanicin $I C_{50}$ Inhibitory Concentration against Elastase}

The inhibitory $\mathrm{IC}_{50}$ concentration of Osmanicin against elastase was assayed by using serial dilutions of Osmanicin $(1 \mu \mathrm{M}$ to $5 \mu \mathrm{M})$. After $24 \mathrm{~h}$ of treatment, the elastase activity was measured as described above. The relative (\%) inhibition per concentration of the compound was calculated and the $\mathrm{IC}_{50}$ value was determined; the elastase activity of control cells (treated with the solvent) was arbitrarily set to $100 \%$.

\subsection{Cell Survival Assay}

The effect of osmanicin on the viability of BJ fibroblasts was examined using the MTT assay [36]. Briefly, cells were plated in flat-bottomed 96-well microplates and the next day they were incubated with different concentrations of osmanicin for $24 \mathrm{~h}$. Following treatment, the medium was replaced by 3-(4,5-dimethylthiazol-2-yl)-2,5-diphenyltetrazolium bromide (MTT, Sigma-Aldrich) dissolved at a final concentration of $1 \mathrm{mg} / \mathrm{mL}$ in serum-free, phenol red-free medium. The formed formazan crystals were then dissolved by isopropanol and the absorbance of the solution was measured at $570 \mathrm{~nm}$ wavelength. Values from control cells were arbitrarily set to $100 \%$.

\subsection{Statistical Analysis}

Experiments were performed at least in duplicate unless otherwise indicated in figure legends. For statistical analyses, MS Excel and the Statistical Package for Social Sciences (IBM SPSS; version 19.0 for Windows) were used. Statistical significance was evaluated using one-way analysis of variance (ANOVA). Data points correspond to the mean of the independent experiments and error bars denote standard deviation (SD). 
Supplementary Materials: The following are available online at http://www.mdpi.com/1420-3049/24/12/2239/s1, reporting different spectral analysis of compound 1. Figure S1. ${ }^{1} \mathrm{H}-\mathrm{NMR}$ spectrum, Figure S2. ${ }^{13} \mathrm{C}-\mathrm{NMR}$ spectrum, Figure S3. HSQC spectrum, Figure S4. HMBC spectrum, Figure S5. ${ }^{1} \mathrm{H}-{ }^{1} \mathrm{H}$ COSY spectrum, Figure S6. ${ }^{1} \mathrm{H}-{ }^{1} \mathrm{H}$ ROESY spectrum, Figure S7. HRESIMS, Figure S8. IR spectrum.

Author Contributions: G.L.G., M.N.S., and P.L. performed large-scale cultivation, metabolite extraction and structural elucidation, K.G. and N.F. contributed to metabolite analysis and editing of the manuscript, N.F. is the coordinator of FP7 EU-project Microsmetics and managed the funding of this work, S.G. and I.T. performed bioassays and edited the manuscript. C.A., I.G. and O.G. managed the microbial collection, performed the identification and classification of the strains and edited the manuscript. J.O. writes the paper and managed the experimental design.

Funding: This work has been financially supported by EU under the frame of MICROSMETICS project (FP7-PEOPLE- Industry-Academia Partnerships and Pathways), Grant agreement No. 612276

Conflicts of Interest: The authors declare no conflict of interest.

\section{References}

1. Hwang, K.-S.; Kima, H.U.; Charusanti, P.; Palsson, B.Ø.; Lee, S.Y. Systems biology and biotechnology of Streptomyces species for the production of secondary metabolites. Biotechnol. Adv. 2014, 32, $255-268$. [CrossRef] [PubMed]

2. Chaudhary, A.M.; Dhakal, D.; Sohng, J.K. An Insight into the "-Omics" Based Engineering of Streptomycetes for Secondary Metabolite Overproduction. BioMed. Res. Int. 2013, 2013, 968518. [CrossRef] [PubMed]

3. Le Goff, G.; Martin, M.-T.; Iorga, B.I.; Adelin, I.; Servy, C.; Cortial, S.; Ouazzani, J. Isolation and Characterization of Unusual Hydrazides from Streptomyces sp. Impact of the Cultivation Support and Extraction Procedure. J. Nat. Prod. 2013, 76, 142-149. [PubMed]

4. Markus Nett, M.; Ikeda, H.; Moore, B.S. Genomic basis for natural product biosynthetic diversity in the actinomycetes. Nat. Prod. Rep. 2009, 26, 1362-1384. [CrossRef] [PubMed]

5. Georgousaki, K.; Katsinas, N.; Tsafantakis, N.; Gumeni, S.; Oves-Costales, D.; González, I.; Almeida, C.; Genilloud, O.; Trougakos, I.N.; Fokialakis, N. Actinobacteria of global biodiversity as a source of bioactive metabolites for the discovery and development of novel cosmeuceutical agents. PMIO 2017, 4, S1-S202.

6. Imokawa, G.; Ishida, K. Biological mechanisms underlying the ultraviolet radiation-induced formation of skin wrinkling and sagging I: Reduced skin elasticity, highly associated with enhanced dermal elastase activity, triggers wrinkling and sagging. Int. J. Mol. Sci. 2015, 16, 7753-7775. [CrossRef] [PubMed]

7. Rittie, L.; Fisher, G.J. UV-light-induced signal cascades and skin aging. Ageing Res. Rev. 2002, 1, 705-720. [CrossRef]

8. Robert, L.; Molinari, J.; Ravelojaona, V.; Andrès, E.; Robert, A.M. Age- and passage-dependent upregulation of fibroblast elastase-type endopeptidase activity. Role of advanced glycation endproducts, inhibition by fucose- and rhamnose-rich oligosaccharides. Arch. Gerontol. Geriatr. 2010, 50, 327-331. [CrossRef] [PubMed]

9. Le Goff, G.; Martin, M.-T.; Servy, C.; Cortial, S.; Lopes, P.; Bialecki, A.; Smadja, J.; Ouazzani, J. Isolation and Characterization of $\alpha, \beta$-Unsaturated $\gamma$-Lactono-Hydrazides from Streptomyces sp. J. Nat. Prod. 2012, 75, 915-919. [CrossRef]

10. Adelin, E.; Servy, S.; Martin, M.-T.; Arcile, G.; Iorga, B.I.; Retailleau, P.; Bonfill, M.; Ouazzani, J. Bicyclic and tetracyclic diterpenes from a Trichoderma symbiont of Taxus baccata. Phytochemistry 2014, 97, 55-61. [CrossRef] [PubMed]

11. Djinni, I.; Djoudi, W.; Souagui, S.; Rabia, F.; Rahmouni, S.; Mancini, I.; Kecha, M. Streptomyces thermoviolaceus SRC3 strain as a novel source of the antibiotic adjuvant streptazolin: A statistical approach toward the optimized production. J. Microbial. Meth. 2018, 148, 161-168. [CrossRef] [PubMed]

12. Puder, C.; Krastel, P.; Zeeck, A. Streptazones A, B1, B2, C, and D: New piperidine alkaloids from streptomycetes. J. Nat. Prod. 2000, 63, 1258-1260. [CrossRef] [PubMed]

13. Tarazona, G.; Schleissner, C.; Rodríguez, P.; Pérez, M.; Cañedo, L.M.; Cuevas, C. Streptenols F-I Isolated from the Marine-Derived Streptomyces misionensis BAT-10-03-023. J. Nat. Prod. 2017, 80, 1034-1038. [CrossRef] [PubMed] 
14. Lee, H.S.; Shin, H.J.; Jang, K.H.; Kim, T.S.; Oh, K.B.; Shin, J. Cyclic peptides of the nocardamine class from a marine-derived bacterium of the genus Streptomyces. J. Nat. Prod. 2005, 68, 623-625. [CrossRef] [PubMed]

15. Wang, G.Y.S.; Graziani, E.; Waters, B.; Pan, W.; Li, X.; McDermott, J.; Davies, J. Novel natural products from soil DNA libraries in a Streptomycete host. Org. Lett. 2000, 2, 2401-2404. [CrossRef]

16. Drautz, H.; Zähner, H. Isolation and structure of streptazolin. Helv. Chim. Acta 1981, 64, $1752-1765$. [CrossRef]

17. Karrer, A.; Dobler, M. Stoffwechselprodukte von mikroorganismen 217. Mitteilung röntgenstrukturanalyse von O-acetyldihydrostreptazolin. Helv. Chim. Acta 1982, 65, 1432-1435. [CrossRef]

18. Awodi, U.R.; Ronan, J.L.; Masschelein, J.; De los Santos, E.L.C.; Challis, G. Thioester reduction and aldehyde transaminationare universal steps in actinobacterial polyketidealkaloid biosynthesis. Chem. Sci. 2017, 8, 411-415. [CrossRef]

19. Byrne, M.J.; Lees, N.R.; Han, L.-C.; Van der Kamp, M.W.; Mulholland, A.J.; Stach, J.E.M.; Willis, C.L.; Paul, R.; Race, P.R. The catalytic mechanism of a natural Diels-Alderase revealed in molecular detail. J. Am. Chem. Soc. 2016, 138, 6095-6098. [CrossRef]

20. Klas, K.; Tsukamoto, S.; Sherman, D.H.; Williams, R.M. Natural Diels-Alderases: Elusive and Irresistible. J. Org. Chem. 2015, 80, 11672-11685. [CrossRef]

21. Watanabe, K.; Mie, T.; Ichihara, A.; Oikawa, H.; Honma, M. An Enzyme-Catalyzed [4+2] Cycloaddition is a Key Step in the Biosynthesis of Spinosyn A. J. Biol. Chem. 2000, 275, 38393-38401. [CrossRef] [PubMed]

22. Eberhardt, N.; Kemter, K.; Richter, G.; Cushman, M.; Bacher, A. Domain structure of riboflavin synthase. Eur. J. Biochem. 2001, 268, 4315-4323. [CrossRef] [PubMed]

23. Eiben, C.B.; Siegel, J.B.; Bale, J.B.; Cooper, S.; Khatib, F.; Shen, B.W.; Players, F.; Stoddard, B.L.; Popovic, Z.; Baker, D. Increased Diels-Alderase activity through backbone remodeling guided by Foldit players. Nat. Biotechnol. 2012, 30, 190-192. [CrossRef] [PubMed]

24. Preiswerka, N.; Becka, T.; Schulza, J.D.; Milovníka, P.; Mayera, C.; Siegel, J.B.; Baker, D.; Hilvert, D. Impact of scaffold rigidity on the design and evolution of an artificial Diels-Alderase. Proc. Natl. Acad. Sci. USA 2014, 111, 8013-8018. [CrossRef] [PubMed]

25. Leman-Loubière, C.; Le Goff, G.; Retailleau, P.; Debitus, C.; Ouazzani, J. Sporothriolide-Related Compounds from the Fungus Hypoxylon monticulosum CLL-205 Isolated from a Sphaerocladina Sponge from the Tahiti Coast. J. Nat. Prod. 2017, 80, 2850-2854. [CrossRef] [PubMed]

26. Seite, S.; Zucchi, H.; Septier, D.; Igondjo-Tchen, S.; Senni, K.; Godeau, G. Elastin changes during chronological and photo-ageing: The important role of lysozyme. J. Eur. Acad. Dermatol. Venereol. 2006, 20, 980-987. [CrossRef] [PubMed]

27. Innis, M.A.; Gelfand, D.H.; Sninsky, J.J.; White, T.J. PCR Protocols: A Guide to Methods and application. Trends Genet. 1990, 6, 229.

28. Weisburg, W.G.; Barns, S.M.; Pelletier, D.A.; Lane, D.J. 16 S ribosomal DNA amplification for phylogenetic study. J. Bacteriol. 1991, 173, 697-703. [CrossRef]

29. Lane, D.J. 16S/23S rRNA sequencing. In Nucleic Acid Techniques in Bacterial Systematics; Stackebrandt, E., Goodfellow, M., Eds.; John Wiley and Sons: New York, NY, USA, 1991; pp. 115-175.

30. Yoon, S.H.; Ha, S.M.; Kwon, S.; Lim, J.; Kim, Y.; Seo, H.; Chun, J. Introducing EzBioCloud: A taxonomically united database of 16S rRNA and whole genome assemblies. Int. J. Syst. Evol. Microbiol. 2017, 67, 1613-1617.

31. Tamura, K.; Stecher, G.; Peterson, D.; Filipski, A.; Kumar, S. MEGA6: Molecular Evolutionary Genetics Analysis version 6.0. Mol. Biol. Evol. 2013, 30, 2725-2729. [CrossRef]

32. Thompson, J.D.; Gibson, T.J.; Plewniak, F.; Jeanmougin, F.; Higgins, D.G. The CLUSTAL_X windows interface: Flexible strategies for multiple sequence alignment aided by quality analysis tools. Nucleic. Acids Res. 1997, 25, 4876-4882. [CrossRef] [PubMed]

33. Saitou, N.; Nei, M. The neighbor-joining method: A new method for reconstructing phylogenetic trees. Mol. Biol. Evol. 1987, 4, 406-425. [PubMed]

34. Jukes, T.H.; Cantor, C.R. Evolution of Protein Molecules. In Mammalian Protein Metabolism; Munro, H.N., Ed.; Academic Press: New York, NY, USA, 1969; pp. 21-132. 
35. Stratford, F.L.; Chondrogianni, N.; Trougakos, I.P.; Gonos, E.S.; Rivett, A.J. Proteasome response to interferon-gamma is altered in senescent human fibroblasts. FEBS Lett. 2006, 580, 3989-3994. [CrossRef] [PubMed]

36. Sklirou, A.D.; Gaboriaud-Kolar, N.; Papassideri, I.; Skaltsounis, A.L.; Trougakos, I.P. 6-bromo-indirubin-3'oxime (6BIO), a Glycogen synthase kinase- $3 \beta$ inhibitor, activates cytoprotective cellular modules and suppresses cellular senescence-mediated biomolecular damage in human fibroblasts. Sci. Rep. 2017, 7, 11713. [CrossRef] [PubMed]

Sample Availability: Samples of osmanicin are available from the authors.

(C) 2019 by the authors. Licensee MDPI, Basel, Switzerland. This article is an open access article distributed under the terms and conditions of the Creative Commons Attribution (CC BY) license (http://creativecommons.org/licenses/by/4.0/). 